\title{
Molecular identification based on coat protein sequences of the Barley yellow dwarf virus from Brazil
}

Talita Bernardon Mar ${ }^{1}$, Douglas Lau ${ }^{2 *}$, Jurema Schons ${ }^{1}$, Elene Yamazaki-Lau², Antônio Nhani Jr. ${ }^{2}$

'UPF/FAMV, Rod. BR 285, São José - 99052-900 - Passo Fundo, RS - Brasil.

2Embrapa Trigo, Rod. BR 285, km 294 - 99001-970 -

Passo Fundo, RS - Brasil.

*Corresponding author < douglas.lau@embrapa.br>

Edited by: Luís Eduardo Aranha Camargo

Received September 24, 2012

Accepted May 02, 2013
ABSTRACT: Yellow dwarf disease, one of the most important diseases of cereal crops worldwide, is caused by virus species belonging to the Luteoviridae family. Forty-two virus isolates obtained from oat (Avena sativa L.), wheat (Triticum aestivum L.), barley (Hordeum vulgare L.), corn (Zea mays L.), and ryegrass (Lolium multiflorum Lam.) collected between 2007 and 2008 from winter cereal crop regions in southern Brazil were screened by polymerase chain reaction (PCR) with primers designed on ORF 3 (coat protein - CP) for the presence of Barley yellow dwarf virus and Cereal yellow dwarf virus (B/CYDV). PCR products of expected size ( $357 \mathrm{bp})$ for subgroup II and ( $831 \mathrm{bp)}$ for subgroup I were obtained for three and 39 samples, respectively. These products were cloned and sequenced. The subgroup II 3' partial CP amino acid deduced sequences were identified as BYDV-RMV (92 - 93 \% of identity with "lllinois" Z14123 isolate). The complete CP amino acid deduced sequences of subgroup I isolates were confirmed as BYDV-PAV (94 - $99 \%$ of identity) and established a very homogeneous group (identity higher than $99 \%$ ). These results support the prevalence of BYDV-PAV in southern Brazil as previously diagnosed by Enzyme-Linked Immunosorbent Assay (ELISA) and suggest that this population is very homogeneous. To our knowledge, this is the first report of BYDV-RMV in Brazil and the first genetic diversity study on B/CYDV in South America.

Keywords: Luteoviridae, Poaceae, small grains, wheat, oat

\section{Introduction}

Yellow dwarf disease (YDD) is one of the most important viral diseases of cereal crops worldwide (Lister and Ranieri, 1995). In South America, it occurs in the Southern cone countries (Ramírez, 1990) and in the Andean countries (Fox et al., 1990). It infects over 150 species of Poaceae and reduces the grain yield of crops such as wheat (Triticum aestivum L.), barley (Hordeum vulgare L.), corn (Zea mays L.), oat (Avena sativa L.), rye (Secale cereale L.), and rice (Oryza sativa L.) (D'Arcy, 1995).

YDD is caused by luteoviruses (Luteoviridae) transmitted by aphids (Aphididae). These virus are limited to the phloem of plant tissues and cause yellowing or reddening of leaves and dwarfing. Virus particles are nonenveloped isometric $(\varnothing 25-30 \mathrm{~nm})$ containing a ss $(+)$ RNA genome (Miller and Rasochová, 1997). According to the most efficient aphid vector (in parentheses) five virus serotypes was discriminated: RPV (Rhopalosiphum padi), RMV (Rhopalosiphum maidis), MAV (Sitobion avenae), SGV (Schizaphis graminum), and PAV (R. padi, S. avenae, and others) (Rochow, 1969; Rochow and Muller, 1971).

The serotypes have been classified into two subgroups: (i) Subgroup I (carmoviruses - like polymerase) includes Barley yellow dwarf virus-PAV (BYDV-PAV), BYDV-MAV, and BYDV-SGV; and (ii) Subgroup II (sobemoviruses - like polymerase) includes BYDV-RMV, Cereal yellow dwarf virus-RPV (CYDV-RPV), and BYDV-GPV species (Koonin and Dolja, 1993; Miller and Rasochová, 1997). Nowadays, based on genomic sequences, three species are classified in the genus Luteovirus (BYDV-PAV,
BYDV-MAV and BYDV-PAS), two species in the genus Polerovirus (CYDV-RPV and CYDV-RPS) and three species were not yet assigned to a genus (BYDV-SGV, BYDVRMV and BYDV-GPV) (D'Arcy and Domier, 2005).

YDD was observed in Brazil in 1929 and their etiology defined based on symptoms and transmissions assays (Caetano, 1968). Survey based on enzyme-linked immunosorbent assay (ELISA) identified BYDV-PAV, MAV and SGV, in Rio Grande do Sul State (Silva et al., 2004). Recent studies on host plants and vectors population confirmed the presence of BYDV-PAV, BYDV-MAV and CYDV-RPV with predominance of BYDV-PAV in Brazilian southern region (Parizoto et al., 2013). In order to obtain detailed information on the virus population, the molecular identification was performed accessing the coat protein (CP) sequence of Brazilian B/CYDV.

\section{Materials and Methods}

\section{Virus isolates}

The 42 isolates that were analyzed in this study were collected between 2007 and 2008 from winter cereal crop regions in southern Brazil (Table 1). These isolates were obtained from oat, wheat, barley, corn, and ryegrass with typical symptoms (yellowing or reddening of leaves and dwarfing) or from aphid vectors present on these plants. To transmit the virus isolate, aphids collected on wheat were transferred to wheat and aphids from other hosts were transferred to oat (because the symptoms are more easily seen on oat than on wheat). Isolates were maintained on hosts according to Parizoto et al. (2013). 
Table 1 - Brazilian isolates used in the sequence comparison.

\begin{tabular}{|c|c|c|c|c|c|c|c|}
\hline \multirow{2}{*}{ Isolate } & \multirow{2}{*}{ Accession number } & \multirow{2}{*}{ Geographic Origin } & \multirow{2}{*}{ State } & \multicolumn{2}{|c|}{ Geographical Coordinates } & \multirow{2}{*}{ Host } & \multirow{2}{*}{ BYDV } \\
\hline & & & & Latitude & Longitude & & \\
\hline PF40_13 & JX067816 & Passo Fundo & RS & $-2814^{\prime} 01,17^{\prime \prime}$ & $-5224^{\prime} 17,25^{\prime \prime}$ & Oat & PAV \\
\hline SJ65_15 & JX067855 & Salto do Jacui & RS & $-2905^{\prime} 21,37 "$ & $-5310^{\prime} 38,68^{\prime \prime}$ & Oat & RMV \\
\hline AA67_17 & JX067817 & Alto Alegre & RS & $-2846^{\prime} 59,19^{\prime \prime}$ & $-5256^{\prime} 14,66^{\prime \prime}$ & Oat & PAV \\
\hline AA67_18 & JX067818 & Alto Alegre & RS & $-2846^{\prime} 59,19^{\prime \prime}$ & $-5256^{\prime} 14,66^{\prime \prime}$ & Oat & PAV \\
\hline S061_19 & JX067856 & Sobradinho & RS & $-2923^{\prime} 44,12^{\prime \prime}$ & -53 02'09,94" & Oat & RMV \\
\hline AA67_21 & JX067857 & Alto Alegre & RS & $-2846^{\prime} 59,19^{\prime \prime}$ & $-5256^{\prime} 14,66^{\prime \prime}$ & Oat & RMV \\
\hline ES68_22 & JX067819 & Espumoso & RS & $-2842^{\prime} 49,21^{\prime \prime}$ & $-5251^{\prime} 12,92^{\prime \prime}$ & Oat & PAV \\
\hline TU69_24 & JX067820 & Tupanciretã & RS & $-2904^{\prime} 06,46^{\prime \prime}$ & $-5353^{\prime} 13,84^{\prime \prime}$ & Oat & PAV \\
\hline SB72_26 & JX067821 & São Borja & RS & $-28400^{\prime} 30,66^{\prime \prime}$ & -55 57'46,18" & Wheat & PAV \\
\hline SB72_27 & JX067822 & São Borja & RS & $-2840^{\prime} 30,66^{\prime \prime}$ & -55 57'46,18" & Wheat & PAV \\
\hline SM54_31 & JX067822 & São Martinho & RS & $-2744^{\prime} 15,82^{\prime \prime}$ & $-5351^{\prime} 33,78^{\prime \prime}$ & Wheat & PAV \\
\hline PL57_33 & JX067824 & Planalto & RS & $-2718^{\prime} 44,18^{\prime \prime}$ & $-5302^{\prime} 56,61^{\prime \prime}$ & Oat & PAV \\
\hline STAM46_35 & JX067824 & St. Antonio Missões & RS & $-2829^{\prime} 22,12^{\prime \prime}$ & $-5514^{\prime} 46,71^{\prime \prime}$ & Wheat & PAV \\
\hline PX51_43 & JX067826 & Porto Xavier & RS & $-2755^{\prime} 30,01^{\prime \prime}$ & $-5508^{\prime} 02,67^{\prime \prime}$ & Oat & PAV \\
\hline STA175_49 & JX067827 & Santo Angelo & RS & -28 22' 27,7" & -54 12' 40,4" & Oat & PAV \\
\hline SLG180_50 & JX067828 & São Luiz Gonzaga & RS & $-2824^{\prime} 27,2^{\prime \prime}$ & -54 43'07,0" & Oat & PAV \\
\hline SLG181_52 & JX067828 & São Luiz Gonzaga & RS & $-2824^{\prime} 27,2^{\prime \prime}$ & -54 43'07,0" & Oat & PAV \\
\hline JA184_54 & JX067830 & Jaguari & RS & $-2926^{\prime} 04,7^{\prime \prime}$ & $-5443^{\prime} 33,4^{\prime \prime}$ & Oat & PAV \\
\hline PI210_56 & JX067830 & Pinhalzinho & SC & $-2649^{\prime} 31,0^{\prime \prime}$ & $-5305^{\prime} 44,4^{\prime \prime}$ & Wheat & PAV \\
\hline TP222_60 & JX067832 & Três Passos & RS & $-2727^{\prime} 05,6^{\prime \prime}$ & $-5354^{\prime} 45,7^{\prime \prime}$ & Oat & PAV \\
\hline MA250_64 & JX067833 & Marialva & PR & $-2330^{\prime} 01,7^{\prime \prime}$ & $-5145^{\prime} 31,1^{\prime \prime}$ & Oat & PAV \\
\hline PA272_66 & JX067834 & Palmeira & PR & $-2529^{\prime} 12,8^{\prime \prime}$ & $-5003^{\prime} 58,4^{\prime \prime}$ & Oat & PAV \\
\hline SMS290_69 & JX067835 & São Mateus do Sul & PR & $-2551^{\prime} 08,4^{\prime \prime}$ & $-5045^{\prime} 20,5^{\prime \prime}$ & Oat & PAV \\
\hline RA334_71 & JX067836 & Ronda Alta & RS & $-2748^{\prime} 05,1^{\prime \prime}$ & -5247 '34,8" & Wheat & PAV \\
\hline CA197_73 & JX067837 & Cruz Alta & RS & $-2838^{\prime} 42,4^{\prime \prime}$ & -53 33' 40,4" & Oat & PAV \\
\hline CA197_75 & JX067838 & Cruz Alta & RS & $-2838^{\prime} 42,4^{\prime \prime}$ & -53 33' 40,4" & Oat & PAV \\
\hline TPA204_76 & JX067839 & Três Palmeiras & RS & $-2733^{\prime} 56,7^{\prime \prime}$ & $-5252^{\prime} 20,6^{\prime \prime}$ & Oat & PAV \\
\hline TPA204_77 & JX067840 & Três Palmeiras & RS & $-2733^{\prime} 56,7^{\prime \prime}$ & $-5252^{\prime} 20,6^{\prime \prime}$ & Oat & PAV \\
\hline JU241_78 & JX067841 & Juranda & PR & $-2421^{\prime} 39,8^{\prime \prime}$ & $-5244^{\prime} 57,3^{\prime \prime}$ & Wheat & PAV \\
\hline C0374_79 & JX067842 & Coxilha & RS & $-2811^{\prime} 41,5^{\prime \prime}$ & $-5219^{\prime} 04,5^{\prime \prime}$ & Barley & PAV \\
\hline C0374_80 & JX067843 & Coxilha & RS & $-2811^{\prime} 41,5^{\prime \prime}$ & $-5219^{\prime} 04,5^{\prime \prime}$ & Barley & PAV \\
\hline C0374_82 & JX067844 & Coxilha & RS & $-2811^{\prime} 41,5^{\prime \prime}$ & $-5219^{\prime} 04,5^{\prime \prime}$ & Barley & PAV \\
\hline C0372_84 & JX067845 & Coxilha & RS & $-2811^{\prime} 41,5^{\prime \prime}$ & $-5219^{\prime} 04,5^{\prime \prime}$ & Ryegrass & PAV \\
\hline CH349_85 & JX067845 & Chapada & RS & $-2800^{\prime} 52,7^{\prime \prime}$ & $-5306^{\prime} 06,0^{\prime \prime}$ & Wheat & PAV \\
\hline SB366_88 & JX067847 & São Borja & RS & $-2841^{\prime} 37,1^{\prime \prime}$ & -55 57' 48,8" & Wheat & PAV \\
\hline AL324_89 & JX067848 & Abelardo Luz & SC & $-2637^{\prime} 16,3^{\prime \prime}$ & -52 21' 29,4" & Wheat & PAV \\
\hline PFR286_90 & JX067849 & Paulo Frontin & PR & $-2604^{\prime} 52,4^{\prime \prime}$ & $-5045^{\prime} 20,5^{\prime \prime}$ & Wheat & PAV \\
\hline ATS347_92 & JX067850 & Alm. Tamandaré do Sul & RS & $-2806^{\prime} 54,5^{\prime \prime}$ & $-5254^{\prime} 24,3^{\prime \prime}$ & Corn & PAV \\
\hline C0373_94 & JX067851 & Coxilha & RS & $-2811^{\prime} 41,5^{\prime \prime}$ & $-5219^{\prime} 04,5^{\prime \prime}$ & Oat & PAV \\
\hline RA203_102 & JX067852 & Ronda Alta & RS & $-2747^{\prime} 23,4^{\prime \prime}$ & $-5249^{\prime} 35,1^{\prime \prime}$ & Wheat & PAV \\
\hline BG216_105 & JX067853 & Barra do Guarita & RS & $-2712^{\prime} 10,1^{\prime \prime}$ & -5342 ' 52,9" & Oat & PAV \\
\hline OR266_107 & JX067854 & Ortigueira & PR & $-2412^{\prime} 12,5^{\prime \prime}$ & $-5056^{\prime} 44,2^{\prime \prime}$ & Oat & PAV \\
\hline
\end{tabular}

\section{RNA isolation}

Plant total RNA was extracted using Rneasy ${ }^{\mathrm{TM}}$ Kit (QIAGEN) according to manufacturer instruction, and stored at $-80^{\circ} \mathrm{C}$. The integrity of the RNA was checked by $1.5 \%$ agarose gel electrophoresis.

\section{Reverse transcription polymerase chain reaction (RT-PCR)}

First strand cDNA was synthesized from total RNA using ImProm- $I I^{\mathrm{TM}}$ Reverse Transcription System Kit (PROMEGA). $1.5 \mu \mathrm{L}$ of the total RNA and 20 pmol of reverse primer Yan-R (Malmstrom and Shu, 2004) were used in each reaction and processed according to manufacturer instruction.

The two sets of primers used for subgroup identification amplify portions of the $3^{\prime}$ region of the $\mathrm{B} / \mathrm{CYDV}$ genome corresponding to ORF 3 (CP). Primers Shu-F and Yan-R targeting $831 \mathrm{bp}$ were used for the identification of subgroup I, and S2a-F and S2b-F (S2a-F for BYDV-RPV and S2b-F for BYDV-RMV) with Yan-R targeting 357 bp were used for subgroup II. Species-specific primers were used for identification of subgroup I species: the 
primers PAV-F and Yan-R targeting $~ 590$ bp were used for BYDV-PAV; MAV-F and Yan-R targeting $590 \mathrm{bp}$ for BYDV-MAV and the pair SGV-R with Shu-F amplifying $\sim 254 \mathrm{bp}$ for BYDV-SGV. All the subgroup and speciesspecific primers were described by Malmstrom and Shu (2004).

The PCR reaction mixture contained $1 \mu \mathrm{L}$ of first strand cDNA, 1 X PCR buffer, $1.5 \mathrm{mM} \mathrm{MgCl}{ }_{2}, 200 \mu \mathrm{M}$ dNTPs, $10 \mu \mathrm{L}$ each forward and reverse primer and 0.625 U of GoTaq ${ }^{\circledR}$ Flexi DNA Polymerase Kit (PROMEGA) in a $20 \mu \mathrm{L}$ reaction volume. The PCR conditions were set to $95{ }^{\circ} \mathrm{C}$ for $2 \mathrm{~min}$ as initial denaturation temperature followed by 35 cycles of $95{ }^{\circ} \mathrm{C}$ for $30 \mathrm{~s}, 55^{\circ} \mathrm{C}$ for $30 \mathrm{~s}$ and $72{ }^{\circ} \mathrm{C}$ for $1 \mathrm{~min}$, respectively, and a final elongation step at $72{ }^{\circ} \mathrm{C}$ for $10 \mathrm{~min}$. Amplified PCR products were analyzed by electrophoresis in $1.2 \%(\mathrm{w} / \mathrm{v})$ agarose gel by ethidium bromide staining $\left(10 \mathrm{mg} \mathrm{mL}^{-1}\right)$. To analyze RFLP patterns (Du et al., 2007), the RT-PCR products generated with YanR and ShuF primers were also digested with the restriction enzyme Hinfl, in a reaction contained $15 \mu \mathrm{L}$ of PCR product, $5 \mathrm{U}$ enzyme (PROMEGA), $1 \mathrm{X}$ buffer in a $20 \mu \mathrm{L}$ reaction volume. The restriction products were then analyzed by electrophoresis in 1.5 $\%(\mathrm{w} / \mathrm{v})$ agarose gel by ethidium bromide staining (10 $\left.\mathrm{mg} \mathrm{mL}{ }^{-1}\right)$.

\section{Cloning of PCR products}

The PCR products amplified using primers for identification of subgroups ( 357 bp for subgroup II and $\sim 831$ bp for subgroup I) were cloned into pGEM-T easy vector (PROMEGA), according to the manufacturer's instructions, and introduced by transformation into $E s$ cherichia coli $\mathrm{DH} 5 \alpha$. Plasmid extraction was performed using Wizard ${ }^{\circledR}$ Plus SV Minipreps DNA Purification Kit (PROMEGA), according to manufacturer instruction. The plasmids were also digested with the restriction enzyme EcoRI for clone confirmation.

\section{Sequencing and sequence analysis}

Sequence reactions were carried out using BigDye ${ }^{\circledR}$ Terminator v3.1 Cycle Sequencing Kit (Applied Biosystems) and run on an ABI 3700 DNA sequencer (Applied Biosystems). One clone per isolate was sequenced in both directions using SP6 and M13 primers. The sequence data were analyzed and assembled in the Phred/Phrap/Consed software package using default parameters (Phred $=20$ ) (Ewing et al., 1998; Ewing and Green, 1998; Gordon et al., 1998). Assembled contigs were manually curated trough analysis of individual read peak quality data, over discrepant regions.

Sequence identities were first verified by nucleotide BLAST (NCBI) search program (Altschul et al., 1990). The amino acid sequence was deduced for complete CP sequences of subgroup I isolates, which consist of 603 nucleotides translated into 201 amino acids. For subgroup II, sequences of 119 amino acids were deduced from 357 nucleotides of $3^{\prime}$ partial CP.
Nucleotide and deduce amino acid sequences were aligned, analyzed and compared with those of the other virus isolates from the family Luteoviridae available in the GeneBank. For comparisons, the sequences were pairwise aligned using the EMBOSS Stretcher Algorithm (http://www.ebi.ac.uk/Tools/psa/emboss_stretcher/). The nucleotide complete CP sequences of Subgroup I were also analyzed by neighbor-joining (Saitou and Nei, 1987), performed using CLUSTAL X with 1.000 bootstrap iterations. Gaps were excluded from the analysis, and all other parameters were set to default values. The phylogenetic trees were visualized using the MEGA5 program (Tamura et al., 2011).

\section{Results}

Forty-two virus isolates collected in southern Brazil between 2007 and 2008 from oat, wheat, barley, corn, and ryegrass with symptoms of the yellow dwarf disease or injured by aphid vectors were analyzed by RT-PCR to confirm the infection by B/CYDV (Table 1 ; Figure 1). Using subgroup-specific primers, 39 isolates were positive for subgroup I ( $831 \mathrm{bp}$ amplification; Figure 2A) and three, originating from oat collected in 2007 in the central region of Rio Grande do Sul, were positive for subgroup II ( 357 bp amplification; Figure 2B).

Subgroup I isolates were analyzed using a species-specific primer. We identified coat protein product amplification from the 39 BYDV isolates as PAV (for an amplification of $\sim 590 \mathrm{bp}$; Figure 2C). None of the isolates produced amplification products following the RTPCR reaction with BYDV-MAV and BYDV-SGV specific

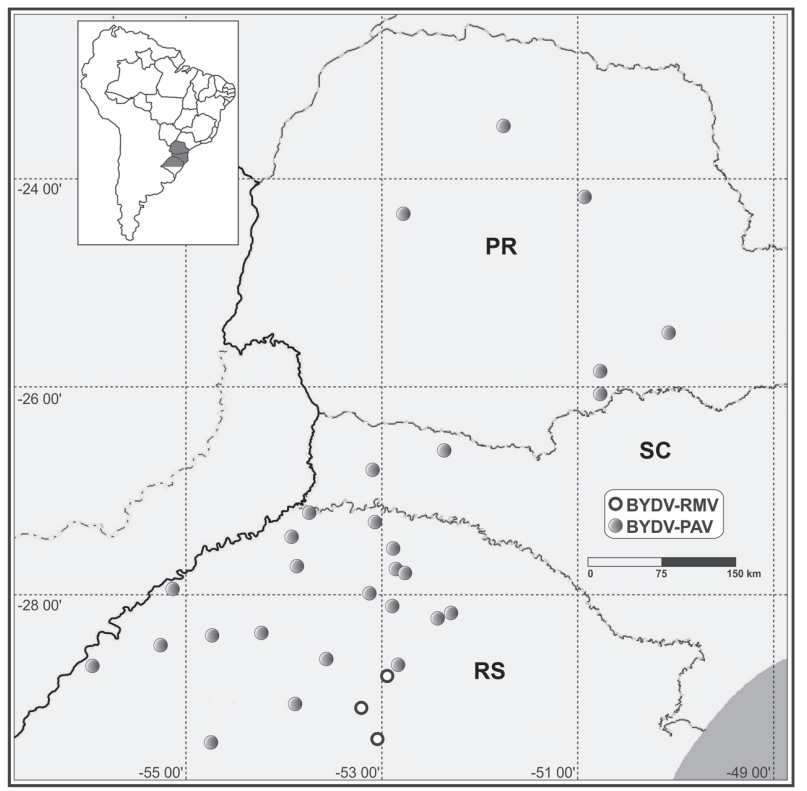

Figure 1 - Distribution map of Barley yellow dwarf virus (BYDV) isolates from the surveyed southern Brazilian cereal crop growing regions. 
primer pair, only faint and unexpected fragments were amplified. The 831 bp subgroup I amplification products were digested with the restriction enzyme Hinfl. We observed two RFLP patterns (Figure 3). One highly homogeneous restriction pattern were obtained from the digestion of the amplification products from 38 BYDVPAV isolates, which generated two fragments of 114 and 629 bp similar to SB72_27 (JX067822). Only the SB72_26 isolate (JX067821) showed a different pattern, with tree fragments of 114,286 and $283 \mathrm{bp}$.

The PCR products amplified using primers for identification of subgroups were cloned, sequenced, subjected to nucleotide BLAST and EMBOSS Stretcher analysis. All the sequences were submitted to GenBank under the accession numbers given in Table 1. Multiple sequence alignment corresponding to the $\mathrm{CP}$ gene were used for the production of a phylogenetic tree to establish the relationship of the Brazilian BYDV-PAV isolates and other selected sequences extracted from the NCBI database (Figure 4).

The three subgroup II isolates were identified as BYDV-RMV with 94 - $95 \%$ of nucleotide and 92 to 93

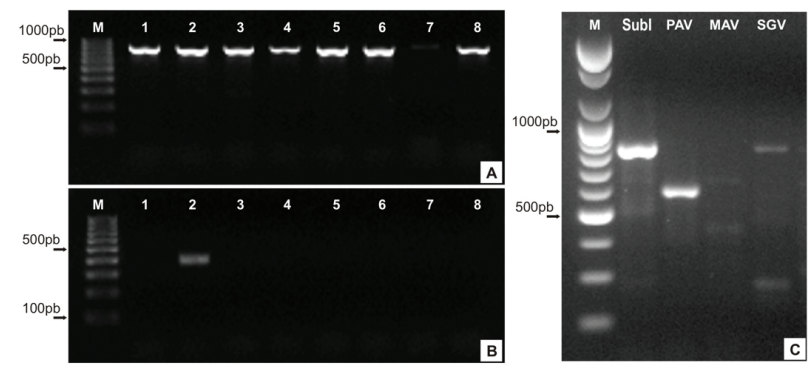

Figure 2 - Agarose gel analysis of RT-PCR assays for detection of $\mathrm{B} / \mathrm{CYDV}$, showing general patterns of the ORF 3 fragments. (A) detection of Subgroup I, amplified with Shu-F and Yan-R targeting 831 bp; (B) detection of Subgroup II amplified with Yan-R and S2a-F and S2b-F targeting 357 bp. For (A) and (B) M: 100 bp DNA ladder (PROMEGA), 1-8: samples analyzed; and (C) pattern of BYDV-PAV (isolate SB72_27) identification with specific primers. M: 100 pb DNA Ladder (BIONEER), Subl: Subgroup I, PAV: BYDV-PAV, MAV: BYDV-MAV, SGV: BYDV-SGV.

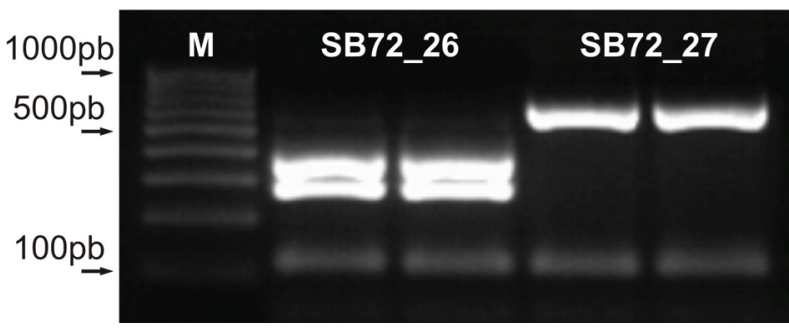

Figure 3 - Hinf I digestion patterns of RT-PCR fragments, amplified with Shu-F and Yan-R ( 830 bp), including the coat protein gene of two BYDV- PAV isolates. Gel codes: M. 100 bp DNA ladder (PROMEGA).
$\%$ of amino acid sequence identity with the "Illinois" (Z14123) isolate. When compared with two other BYDVRMV sequences ("Montana" -L12757 and L12758) isolates) they had $79-84 \%$ of nucleotide and $75-78 \%$ of amino acid identity. The Brazilian BYDV-RMV isolates

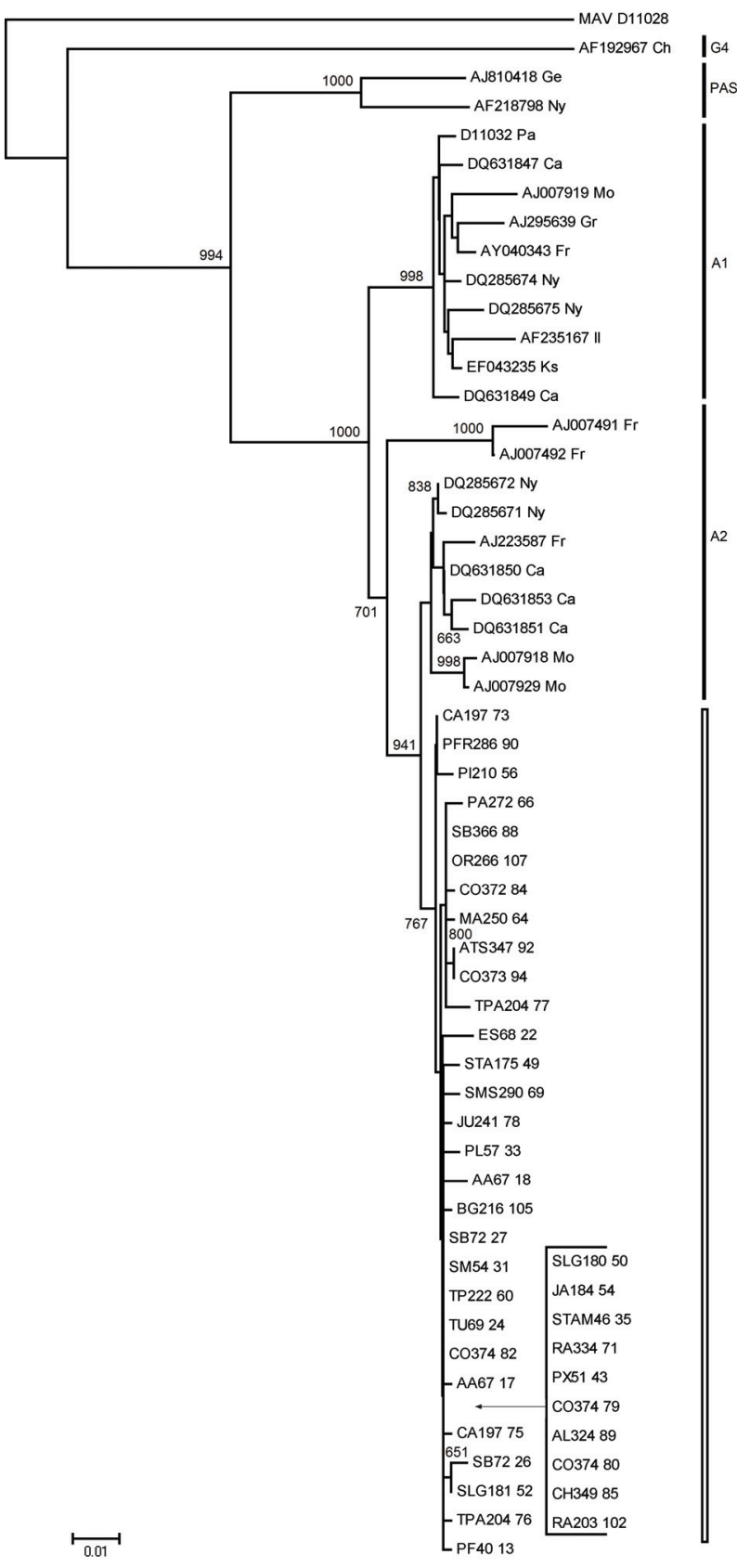

Figure 4 - Phylogenetic relationships among coat protein (CP) gene nucleotide sequences of BYDV-PAV presented in a neighbor-joining tree based on 1,000 bootstrap iterations and rooted with the BYDV-MAV designated as the outgroup. Only posterior probabilities $\geq 0.60$ are shown. The sequences of Brazilian isolates in this study are labeled with a white bar. 
had higher than $98 \%$ of nucleotide and $98 \%$ of amino acid identity among themselves, the SJ65_15 isolate (JX067855) being the most divergent, differing in two amino acids from AA67_21 (JX067857) and SO61_19 (JX067856).

Other 39 isolates were confirmed as BYDV-PAV. The sequence of the CP gene nucleotide average identity compared to other BYDV- PAV isolates was higher than $95 \%$ of nucleotide and $97 \%$ of amino acid identity. All of the Brazilian BYDV-PAV were closely related and established a very homogeneous cluster (nucleotide and amino acid identity between $99-100 \%$, independent of locality, year and host). The AA67_18 (JX067818) isolate showed three divergent amino acids and other nine isolates differing in one amino acid compared with the Brazilian isolates.

The SB72_26 isolate (JX067821) which showed a different restriction pattern was closely related to other Brazilian BYDV-PAV isolates, differing only in four nucleotide and one amino acid from PF40_13 (JX067816). The different restriction pattern occurs due to a substitution of cytosine for thymine at codon 38 , which results in a proline $\rightarrow$ leucine mutation.

The CP nucleotide sequences of PF40_13 Brazilian BYDV-PAV isolate when compared with clades proposed by Malmstrom et al. (2007), showed the highest nucleotide sequence identity $(98-99 \%)$ with isolates from the subgroup A2 of BYDV-PAV (excepted when compared with French isolates: AJ007491 and AJ007492 which had 95 and $96 \%$ of identity respectively). The CP sequence of the Brazilian BYDV-PAV shared 95 to $97 \%$ of identity with sequence of the subgroup A1, $91 \%$ with the PAS clade and $82 \%$ with the monotypic variant G4 (PAV-CN, AF192967) (Liu et al., 2007).

\section{Discussion}

YDD is widespread in cereal growing regions, reducing grain yield (Lister and Ranieri, 1995). Although it is not seed-borne, YDD is broadly dispersed by numerous aphid species and the virus can infect many cultivated and wild grass species (D'Arcy, 1995). The pathosystem is complex, with many grass hosts, aphid vectors, and virus species that have competitive and synergistic interactions with each other and can be influenced by the environment (Irwin and Thresh, 1990). In order to understand one component of this pathosystem, this study assessed the genetic diversity on CP gene sequence of viruses associated with YDD in wheat-growing areas of southern Brazil.

The first evidence of the existence of a high diversity in virus population associated with YDD in Brazil was obtained by biological studies. The authors indicated the presence of isolates with vector-specific transmission as well as isolates with vector-non-specifc transmission by $R$. padi, $R$. maidis, $S$. avenae, $M$. dirhodum and $S$. graminum. There was also variation in symptom severity for vector-specific isolates, which indicated pathogenic variability in the 1970s (Ramírez, 1990). In the 1990s, studies on virus population were carried out using ELISA to identify the virus. These studies indicated the occurrence of BYDVPAV, BYDV-MAV and BYDV-SGV in Brazilian samples (Webby et al., 1993) which was also observed in the 2000s (Silva et al., 2004). In Argentina, serological tests demonstrate the existence of five BYDV species: PAV, MAV, SGV, RPV and RMV, and BYDV-PAV was the most common species (Truol, 2002). The diversity of $\mathrm{B} / \mathrm{CYDV}$ species in Argentina indicated that probably other species may occur in wheat-growing areas of southern Brazil.

The PCR used in this study allowed the detection of two subgroups and the identification of subgroup I species. Of the 42 isolates tested for identification of subgroups, three were positive for subgroup II and 39 positive for subgroup I. They were tested with specific primers to BYDV-PAV, BYDV-MAV, and BYDV-SGV. All of the subgroup I samples were positive for BYDV-PAV. None of the subgroup I isolates we tested showed positive reaction to the BYDV-MAV or BYDV-SGV specific primer pair.

We compared the nucleotide and amino acid sequence of the 3' region, amplified portions corresponding to ORF3 $(\mathrm{CP})$. The separation into species was based upon criteria that $>10 \%$ differences at the amino acid level for any viral gene product, discriminates between species within the Luteoviridae (D'Arcy and Domier, 2005). All of the subgroup I isolates previously identified by PCR were confirmed as BYDV-PAV, suggesting that this species is predominant in wheat-growing areas of southern Brazil. The three subgroup II samples were identified as BYDV-RMV.

Some authors assert that there is a correlation of aphid species with the incidence of B/CYDV species. Usually, the predominance of the BYDV-PAV and the efficient vector $R$. padi have been associated with epidemics and yield loss in cereal growing areas (Chapin et al., 2001; Gray et al., 1998). The prevalence of BYDV-PAV in Brazilian growing areas is in line with recent indications of the predominance of the $R$. padi vector in the field (Silva et al., 2004; Parizoto et al., 2013). A study of the predominant species of the virus in weeds in Argentina demonstrates that BYDV-PAV, CYDV-RPV, and BYDVRMV were the dominant species, which could be related to the abundance of $R$. padi, found to be an efficient vector of those species in transmission studies (Truol, 2002). The presence of BYDV-PAV and BYDV-RMV and predominance of $R$. padi areas are similar to those found in our study.

We also studied the genetic diversity between BYDV-PAV and BYDV-RMV species found in Brazilian growing areas. Based on sequencing, BYDV-PAV was initially subdivided into two subgroups, A and B, with about $90 \%$ amino acid sequence homology in the $\mathrm{CP}$ gene. The B group nowadays has been identified as BYDV-PAS and cannot be distinguished from BYDV-PAV 
by serology, but is differentiated by restriction pattern analysis (Bencharki et al., 1999; Mastari et al., 1998). Other species could be distinguished after cleavage with HinfI (Du et al., 2007). Even though one isolate showed a distinct restriction pattern, the 39 subgroup I Brazilian samples were confirmed as BYDV-PAV and were closely related (99-100 \% of amino acid identity).

The diversity of BYDV-PAV isolates was low considering that the analyses include isolates from different hosts, years, and localities. Coat proteins of PAV isolates within subgroup A ranged from 93 to $100 \%$ amino acid sequence identity (Mastari et al., 1998). In the phylogenetic analyses, the Brazilian BYDV-PAV isolates were more similar to subgroup A2. The phylogenetic organization of the subgroup was based on the one proposed by Malmstrom et al. (2007), who considered that subgroup A can be subdivided into A1 and A2 and that they were not geographically defined. While BYDV-PAV isolates appear not to depend on different hosts, years and localities, BYDV-RMV was found only in oat collected in 2007 in the central region of Rio Grande do Sul.

The prevalence of BYDV-PAV in the Brazilian winter cereal crop regions and the conserved nature of the $\mathrm{CP}$ gene of Brazilian BYDV-PAV isolates possibly allow for pathogen-derived resistance strategies (McGrath et al., 1997) for controlling plant viral diseases, eventually minimizing yield and quality losses.

We report the identification of subgroups by PCR and provide the first genetic diversity study on Brazilian BYDV isolates based on the $\mathrm{CP}$ gene sequence. These results are novel for this group of viruses in South America, because there is no study of phylogenetic relationship of local viruses in comparison with other isolates from the Luteoviridae family. Despite the limited number of isolates, we found two B/CYDV species, and the prevalence of BYDV-PAV in the southern Brazilian cereal crop region. This prevalence was previously determined by ELISA. The genetic variability between BYDV-PAV isolates is low, indicating the prevalence of the A2 subgroup of BYDV-PAV. This is also the first report of BYDV-RMV species in Brazil.

\section{References}

Altschul, S.F.; Gish, W.; Miller, W.; Mayers, E.W.; Lipman, D.J. 1990. Basic local alignment search tool. Journal of Molecular Biology 215: 403-410.

Bencharki, B.; Mutterer, J.; El Yamani, M.; Ziegler-Graff, V.; Zaoui, D.; Jonard, G. 1999. Severity of infection of Moroccan Barley yellow dwarf virus PAV isolates correlates with variability in their coat protein sequences. Annals of Applied Biology 134: 89-99.

Caetano, V.R. 1968. First note of the occurrence of a virus disease in winter cereals in Rio Grande do Sul. Revista da Sociedade Brasileira de Fitopatologia 2: 53-66 (in Portuguese, with abstract in English).
Chapin, J.W.; Thomas, J.S.; Gray, S.M.; Smith, D.M.; Halbert, S.E. 2001. Seasonal abundance of aphids (Homoptera: Aphididae) in wheat and their role as Barley yellow dwarf virus vectors in the South Carolina coastal plain. Journal of Economic Entomology 94: 410-421.

Du, Z.Q.; Li, L.; Liu, L.; Wang, X.F.; Zhou, G. 2007. Evaluation of aphid transmission abilities and vector transmission phenotypes of Barley yellow dwarf viruses in China. Journal of Plant Pathology 89: 251-259.

D'Arcy, C.J. 1995. Symptomology and host range of Barley yellow dwarf. p. 9-28. In: D'Arcy, C.J.; Burnett, P.A., eds. Barley yellow dwarf: 40 years of progress. APS Press, St. Paul, MN, USA.

D'Arcy, C.J.; Domier, L.L. 2005. Family luteoviridae. p. 891-900. In: Fauquet, C.M.; Mayo, M.A.; Maniloff, J.; Desselberger, U.; Ball, L.A., eds. Virus taxonomy: classification and nomenclature of viruses. Elsevier Academic Press, San Diego, CA, USA. (Eighth Report of the International Committee on the Taxonomy of Viruses).

Ewing, B.; Green, P. 1998. Base-calling of automated sequencer traces using Phred. II. Error probabilities. Genome Research 8: 186-194.

Ewing, B.; Hillier, L.; Wendl, M.C.; Green, P. 1998. Base-calling of automated sequencer traces using Phred. I. Accuracy assessment. Genome Research 8: 175-185.

Fox, P.N.; Tola, J.; Chicaiza, O. 1990. Barley yellow dwarf in the Andean countries of South America. p. 25-28. In: Burnett, P.A., ed. World perspectives on Barley yellow dwarf. CIMMYT, Mexico, DF, Mexico.

Gordon, D.; Abajian, C.; Green, P. 1998. Consed: a graphical tool for sequence finishing. Genome Research 8: 195-202.

Gray, S.M.; Chapin, J.W.; Smith, D.M.; Banerjee, N.; Thomas, J.S. 1998. Barley yellow dwarf luteoviruses and their predominant vectors in winter wheat grown in South Carolina. Plant Disease 82: 1328-1333.

Irwin, M.E.; Thresh, J.M. 1990. Epidemiology of Barley yellow dwarf: a study in ecological complexity. Annual Review of Phytopathology 28: 393-424.

Koonin, E.V.; Dolja, V.V. 1993. Evolution and taxonomy of positive strand RNA viruses: implications of comparative analysis of amino acid sequences. Critical Reviews in Biochemistry and Molecular Biology 28: 375-430.

Lister, R.M.; Ranieri, R. 1995. Distribution and economic importance of Barley yellow dwarf. p. 29-53. In: D'Arcy, C.J.; Burnett, P.A., eds. Barley yellow dwarf: 40 years of progress. APS Press, St. Paul, MN, USA.

Liu, F.; Wang, X.; Liu, Y.; Xie, J.; Gray, S.M.; Zhou, G.; Gao, B. 2007. A Chinese isolate of Barley yellow dwarf virus-PAV represents a third distinct species within the PAV serotype. Archives of Virology 152: 1365-73.

Malmstrom, C.M.; Shu, R. 2004. Multiplex RT-PCR for streamlined detection and separation of Barley and Cereal yellow dwarf viruses. Journal of Virological Methods 120: 69-78.

Malmstrom, C.M.; Shu, R.; Linton, E.W.; Newton, L.A.; Cook, M.A. 2007. Barley yellow dwarf viruses (BYDVs) preserved in herbarium specimens illuminate historical disease ecology of invasive and native grasses. Journal of Ecology 95: 11531166 . 
Mastari, J.; Lapierre, H.; Dessens, J.T. 1998. Asymmetrical distribution of Barley yellow dwarf virus PAV variants between host plant species. Phytopathology 88: 818-821.

McGrath, P.F.; Vincent, J.R.; Lei, C.-H.; Pawlowski, W.P.; Torbert, K.A.; Gu, W.; Kaeppler, H.F.; Wan, Y.; Lemaux, P.G.; Rines, H.R.; Somers, D.A.; Larkins, B.A.; Lister, R.M. 1997. Coat protein mediated resistance to isolates of Barley yellow dwarf in oats and Barley. European Journal of Plant Pathology 103: 695-710.

Miller, W.A.; Rasochová, L. 1997. Barley yellow dwarf viruses. Annual Review of Phytopathology 35: 167-190.

Parizoto, G.; Rebonatto, A.; Schons, J.; Lau, D. 2013. Barley yellow dwarf virus-PAV in Brazil: seasonal fluctuation and biological characteristics. Tropical Plant Pathology 38: 11-19.

Ramírez, A.I. 1990. A review of Barley yellow dwarf in the Southern Cone countries of South America. p. 29-34. In: Burnett, P.A., ed. World perspectives on Barley yellow dwarf. CIMMYT, Mexico, DF, Mexico.

Rochow, W.F. 1969. Biological properties of four isolates of Barley yellow dwarf virus. Phytopathology 59: 1580-1589.

Rochow, W.F.; Muller, I. 1971. A fifth variant of Barley yellow dwarf virus in New York. Plant Disease 55: 874-877.
Saitou, N.; Nei, M. 1987. The neighbor joining method a new method for reconstructing phylogenetic trees. Molecular Biology and Evolution 35: 406-425.

Silva, M.T.B.; Costa, E.C.; Balardin, R.S. 2004. Cultivars reaction and efficiency of chemical control of aphids vectors of Barley yellow dwarf virus in wheat. Ciência Rural 34: 1333-1340 (in Portuguese, with abstract in English).

Tamura, K.; Peterson, D.; Peterson, N.; Stecher, G.; Nei, M.; Kumar, S. 2011. MEGA5: Molecular Evolutionary Genetics Analysis using maximum likelihood, evolutionary distance, and maximum parsimony methods. Molecular Biology and Evolution 28: 2731-2739.

Truol, G. 2002. Barley yellow dwarf virus in Argentina. p. 53-54. In: Henry, M.; McNab, A., eds. Barley yellow dwarf disease: recent advances and future strategies. CIMMYT, Texcoco, Mexico.

Webby, G.N.; Lister, R.M.; Burnett, P.A. 1993. The occurrence of Barley yellow dwarf viruses in CIMMYT bread wheat nurseries and associated cereal crops during 1988-1990. Annals of Applied Biology 123: 63-74. 